\title{
Assessment of hydrological regimes for vegetation on riparian wetlands in Han River Basin, Korea
}

\author{
Jaewon Kwak ${ }^{1}$, Gilho Kim ${ }^{2, *}$, Jungwook Kim ${ }^{3}$, Vijay P. Singh ${ }^{4}$, and Hung Soo Kim ${ }^{3}$ \\ ${ }^{1}$ Forecast and Control Division, Nakdong River Flood Control Office, Busan, Korea \\ ${ }^{2}$ Hydro Science and Engineering Research Institute, Korea Institute of Civil Engineering and Building Technology, Goyang-si, \\ Gyeonggi-Do, Korea \\ ${ }^{3}$ Department of Civil Engineering, Inha University, Incheon, Korea \\ ${ }^{4}$ Department of Biological \& Agricultural Engineering and Zachry Dept. of Civil Engineering, Texas A \& M University, TX, USA
}

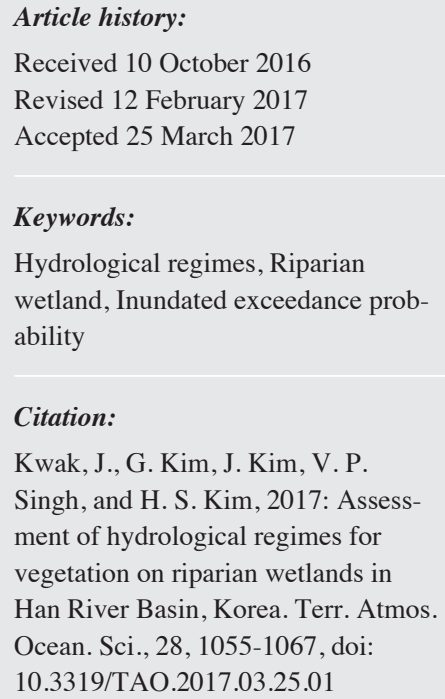

\begin{abstract}
Hydrological regimes are regarded as one of the major determinants for wetland ecosystems, for they influence species composition, succession, productivity, and stability of vegetation communities. Since Korea launched the Four Major River Restoration Project in 2007, the water regimes of many of the riparian wetlands have changed, that is potentially affecting vegetation properties. For ecological conservation and management, it is important to connect hydrological characteristics and vegetation properties. The objective of this study is to investigate the influence of hydrological regimes on vegetation community, and develop a methodology that can connect them. Inundated exceedance probability (IEP) and its district concept are suggested to gain insights into hydrological regimes on the Binae wetland that is rehabilitated by the Restoration Project in 2012 and belong to the riparian zone. Results of this study indicate that the areas with $\mathrm{P}=0.08$ or lower IEPs should have the disturbance for vegetation communities, or could be changed to a hydrophilic vegetation in the study area, and it should be considered in the restoration and rehabilitation project to conserve legally protected or endangered vegetation.
\end{abstract}

\section{INTRODUCTION}

In many cases, development activities have caused considerable damage to the biological diversity in wetlands and riparian lands. Many remaining riverine wetlands are cultivated for agricultural purposes (Rich and Woodruff 1996; McCollin et al. 2000). During the last four decades, many riparian floodplains, grasslands, and wetlands have been integrated into urban and agricultural areas in South Korea (Rho 2007); accordingly, wetland restoration and conservation are being emphasized by society as well as in government policies (Kim et al. 2011). Also, wetland functions and ecosystems depend on hydrological regimes; therefore, climate change exercises a significant impact on wetlands and associated species (Wall 1998; Eliot et al. 1999; Dawson et al. 2003; Johnson et al. 2005; Acreman et al. 2009). To successfully rehabilitate wetlands, the relationship between

\footnotetext{
* Corresponding author

E-mail:kgh0518@kict.re.kr
}

abiotic and biotic factors, such as water level and inundation condition, plant communities, and nutrients in the water, is essential (Wassen et al. 2003). Consequently, many studies have focused on the relationship between environmental and biotic factors (Cellot et al. 1994; Large et al. 1994; Van Oorschot et al. 1997; Bridgham et al. 1998; Keddy and Fraser 2000).

One of the main factors that affect vegetation in wetlands is the water level fluctuation, as high water levels kill emergent vegetation, whereas low water levels following these highs result in seed germination and growth of a multitude of species (Environment Canada 2002), because plant species and communities have an affinity for certain water-depth ranges (Keddy 2000). For instance, Phragmites japonica (Phragmites japonica Steud) has been shown to favor locations with longer and deeper inundation (Seo et al. 2011), but sawgrass (Cladium jamaicense) tends to avoid these locations (Busch et al. 1998). Moreover, the timing and duration of flooding have a great effect on successful 
settlement of annual and biennial plants without rhizome (Nam et al. 2015).

Gunderson (1994) suggested that the duration and depth of inundation constitute the major hydrologic regime controlling plant distribution in a Florida national park. Also, Wilcox and Nichols (2008) pointed out the waterlevel fluctuation as the dominant condition in the Lake $\mathrm{Hu}$ ron wetlands. Many studies have indicated that hydrological regime is one of the important constraints for vegetation distribution (Howard-Williams 1975; Hughes 1990; Jean and Bouchard 1993; Agostinho et al. 2004; Frieswyk and Zedler 2007; Aroviita and Hämäläinen 2008). Of course, it has been argued that the hydrology in vegetation communities is less than clear because the communities interact with other variables, such as nutrients, soil characteristics, and biota (Busch et al. 1998; Zweig and Kitchens 2008). However, Yu and Wang (2012) and others (Kennedy et al. 2003; Boar 2006) have found the environmental flow control schemes to be the cause of partial degradation of vegetation in the Ejina Delta, China. Some studies suggest that different kinds of vegetation communities can be segregated along hydrologic gradients (Olmsted and Armentano 1997; Busch et al. 1998; Ross et al. 2003). Therefore, it seems clear that hydrological regime is a significant reason for vegetation communities and distribution. But undisturbed ecosystems (Lenders et al. 1999) without significant human influence are required in order to verify the effect of hydrologic regime, otherwise the effect becomes murky (Girel 1994; Tremolieres et al. 1994; Large 1997). Although many studies on wetland plant communities have confirmed the effect of hydrological regime but observed data have not been collected (Keddy 2000).

In 2012, South Korea completed the Four Major River Restoration Project (Cha et al. 2011) which will significantly change the hydrological regime. Totally 16 barrages were constructed in South Korea, and the project has flow controls and storages with gate operations, including inundation frequency, duration and depth. Therefore, the ecosystem and vegetation will also significantly change, because hydrological characteristics are considered as the major driving forces for the wetland ecosystem and vegetation (Mitsch and Gosselink 2007). However, there are very few studies that have examined these regimes and wetlands.

The objective of this study therefore was to determine the relationship between hydrological regime and vegetation gradient on the newly constructed wetlands that have changing plant successions. The Binae wetland in the mainstream of the Han River was selected and investigated for hydrological and vegetation distribution for 4 years from the year of construction in 2012. The hydrological regime was analyzed based on the exceedance probability of flooding, 2-dimensional inundation analysis module was developed and optimized for the study area, and hydrological and ecological field surveys were conducted. The relationship between hydrological regime, such as inundation depth and frequencies, and vegetation distribution and vegetation communities was analyzed, and then the vulnerability of vegetation in the future was suggested.

\section{METERIALS AND METHODOLOGY}

\subsection{Study Area and Field Survey}

The Binae wetland, which is an alluvial island with a $0.7 \mathrm{~km}^{2}$ area with flow between 50 and $1200 \mathrm{~m}^{3} \mathrm{~s}^{-1}$, is a riparian and riverine wetland in the mainstream of the Han River, located in the middle of the Namhan River basin, South Korea (Fig. 1). It was rehabilitated by 4 Major River Restoration Project (2007 - 2012) as the natural environment conservation area, and was chosen with the hope that it shows the hydrological and ecological succession. The elevation of the Binae wetland and adjoining areas were obtained from 2012 to 2015 with Trimble R4 RTK GPS $( \pm 2 \mathrm{~cm})$. Other physical properties of the Binae wetland were obtained from a 10 $\times 10 \mathrm{~m}$ grid DEM and land-use map (National Geographic Information Institute, http://map.ngii.go.kr/). Streamflow characteristics, which is required for the hydrological regime, including flood duration, frequency and depth, was investigated. Stream flow and river profile were measured with boat type Sontek ADP ${ }^{\circledR}$ (ADCP; $\pm 0.5 \mathrm{~cm} \mathrm{~s}^{-1}$ ), which can provide a detailed profile of water velocity and direction for the majority of a cross section instead of just at point locations with a mechanical current meter and improves on the accuracy for complex river systems (U.S. Geological Survey's Water Science School, http://water.usgs.gov). These acquired data from RTK GPS and ADCP were combined with $10 \times 10 \mathrm{~m} \mathrm{DEM}$, and its combined data were used as topographic input for the TIN and elevation grid (Fig. 2).

Vegetation communities and their distribution of the study area were investigated, based on the National Regulation of Natural Environment Survey and Classification (Ministry of Environment), and the phytosociological survey method (Braun-Blanquet 1964), which considers geography, physiognomy and vegetation sizes of study sites. These methods were chosen, because most of the vegetation surveys in South Korea would follow the same principles, so their results would be compatible with further or future studies. Using a satellite image in April to November 2012, pre-processing included initial survey site boundaries, and draft homogenous areas were conducted in order to investigate vertical and horizontal cross-sectional diagrams of vegetation. Also, the belt transect of survey site and areas were set up, which were used in biology to estimate the distribution of organisms in relation to a certain area (Hill et al. 2005). Eight field surveys before and after rainy season were further made during Fall 2012 to Summer 2015, which focused on fine scale areal details and the species composition. Also, GPS coordinates (WGS 1984, UTM Zone 52N) were taken from each of the survey sites using Trimble R4 RTK GPS $( \pm 2 \mathrm{~cm})$. 


\subsection{2-Dimensional Inundation Analysis}

In a riparian zone, the location of plant species in relation to flooding depth and duration (David 1996), and its mean that the spatial distribution of flooding area and depth during the whole hydrological year could be used as a way to understand vegetation communities. Therefore, to analyze spatial communities and their ecological successions, at least 2-dimensional inundation analysis is essential. Therefore, equations of continuity [Eq. (1)] and motion [Eqs. (2) and (3)] were employed for 2-demensional inundation analysis:

$\frac{\partial h_{z}}{\partial t}+\frac{\partial M}{\partial x}+\frac{\partial N}{\partial y}=0$

$$
\begin{aligned}
& \frac{\partial M}{\partial t}+\frac{\partial(u M)}{\partial x}+\frac{\partial(v N)}{\partial y}=-g h_{z} \frac{\partial H}{\partial x}-\frac{\tau_{b x}}{\rho_{w}} \\
& \frac{\partial M}{\partial t}+\frac{\partial(u M)}{\partial x}+\frac{\partial(v N)}{\partial y}=-g h_{z} \frac{\partial H}{\partial y}-\frac{\tau_{b y}}{\rho_{w}}
\end{aligned}
$$

where $t$ is the time; $x$ and $y$ are the horizontal and the vertical locations in the coordinate system; $h$ is the water level; $u$ is the $\mathrm{x}$-direction velocity component which is combined with $h$ and water surface drift $\eta ; v$ is the y-direction velocity; $H$ is the water level of certain point $\left(H=h_{z}+z\right)$ and $z$ is the ground level; $M$ and $N$ are the flow components of combined velocity $u$ and $v ; \tau_{b x}$ and $\tau_{b y}$ are the shearing stresses of the ground surface of each $x$ and $y$ directions [Eqs. (4) - (5)]:
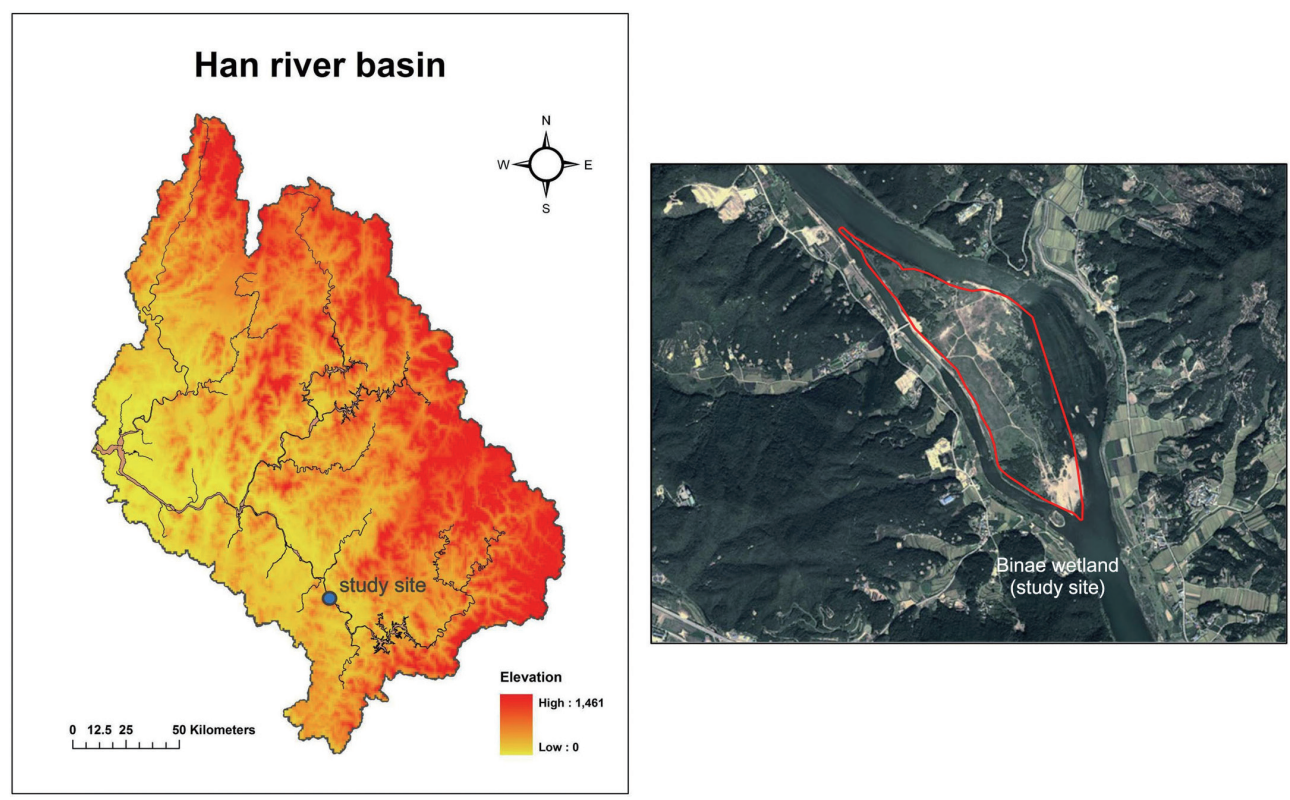

Fig. 1. Location of the study site in the Han River. (Color online only)

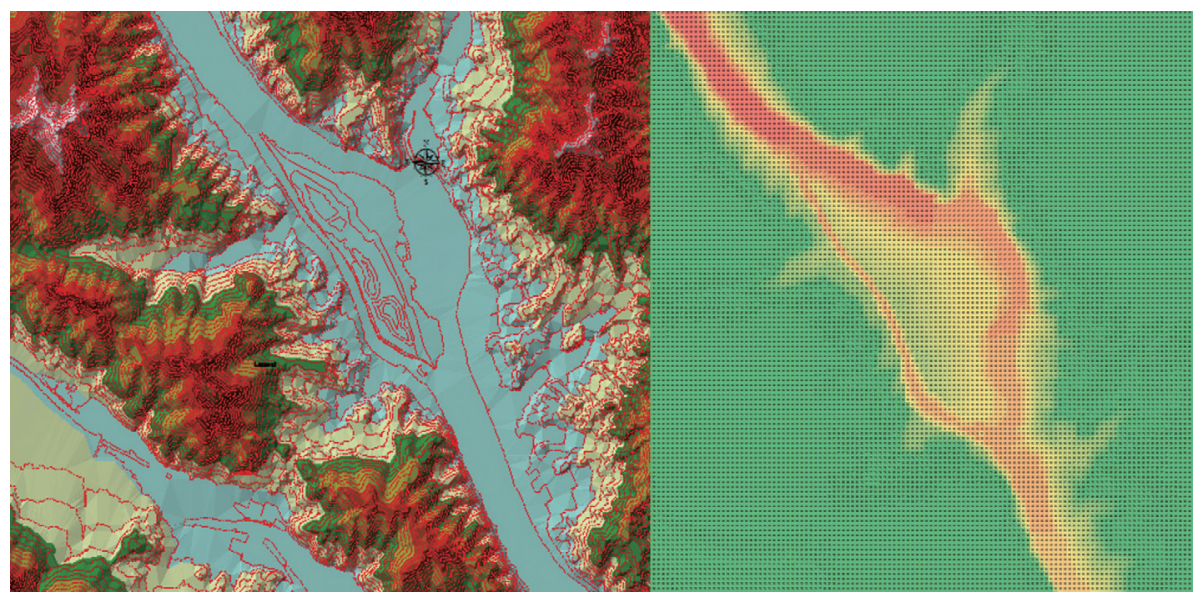

Fig. 2. Constructed triangulated irregular network (TIN) and elevation grid of the study area. (Color online only) 
$\tau_{b x}=\frac{\rho_{u} g n^{2}}{D^{\frac{7}{3}}} M \sqrt{M^{2}+N^{2}}$

$\tau_{b y}=\frac{\rho_{u} g n^{2}}{D^{\frac{7}{3}}} N \sqrt{M^{2}+N^{2}}$

where $\rho_{u}$ is the density of fluid and $n$ is Manning's roughness coefficient. Based on the $10 \times 10 \mathrm{~m}$ DEM (Girel 1994) and Trimble R4 RTK GPS $( \pm 2 \mathrm{~cm})$ measuring result, the 10 $\times 10 \mathrm{~m}$ gridded study area for inundation analysis was constructed. For numerical analysis for inundation, runoff line and its velocities were assumed to be located at the boundary of each grid, and the representative water-level of each grid was assumed to be located at the central point of the grid (Iwasa et al. 1980). Also, the finite difference time domain method was employed for analysis for the composed inundation grid, the forward difference approximation method for duration term, the Doner cell method for the advection term, and the central difference approximation method for shear force on the ground (Suzuki et al. 2014). In addition, the short circuit analysis was applied when the ground level was higher and overflow type analysis was applied when the ground level was lower to prevent overflow discontinuity [Eqs. (6) - (7)].

$M_{0}=\left(\frac{2}{3}\right)^{\frac{3}{2}} h_{h} \sqrt{g h_{h}}$

$M_{0}=0.35 h_{l} \sqrt{2 g h_{l}}$

where $M_{0}$ is the runoff amount, $h_{h}$ is the water-level on the higher ground grid, and $h_{l}$ is the water-level when overflow occurred. Also, the inundated grid was determined when the grid had $\in=0.01 \mathrm{~m}$ or more water-level.

\subsection{Inundated Exceedance Probability and Its District Concept}

The stability of a particular wetland is directly related to its hydrological regime, including the period of shift in surface or sub-surface water levels. Flood duration and frequency give some indication of the time period in which the effects of inundation and soil saturation occur (Scholz and Lee 2005). Strictly speaking, the study area belongs to the river channel or riparian wetland, so the water level fluctuation would be the main constraint factor for the hydrological regime than the sub-surface or underground water level and evapotranspiration. To classify the study area according to flood frequency and duration, annual Inundated Exceedance Probability (hereafter referred to as IEP) and its district concept that is defined as the inundation probability on a particular space or the particular district that belongs to the same probability were suggested and employed. It can be described that the annual fluctuation frequency of water level quantitatively estimates how long riparian zones will be inundated annually. For instance, the area has a $\mathrm{P}=0.01$ IEP when a floodplain has annually 4-day inundation period ( $\mathrm{P}=4 / 365 \fallingdotseq 0.01)$. Also, an area can be classified as a particular area that has the same inundation characteristics. The inundated period and depth, that are the most important factors for determining the kind of plants that inhabit or will be inhabited in riparian zones (Swanson et al. 1982; Hughes 1997; Capon 2005; Catford et al. 2011), can be used as a quantitative indicator for vegetation modelling or prediction. Each runoff amount and water level based on IEP with annual exceedance probability $(\mathrm{P}=0.01,0.03,0.05$, $0.08,0.25,0.50,0.75,0.97)$ was estimated to define the IEP district and its change.

\section{RESULTS AND DISCUSSION}

\subsection{Field Survey: Vegetation Distribution}

Field surveys based on the National Regulation of Natural Environment Survey and Classification and the phytosociological survey method during 2012 to 2015 show that the study area (Binae wetland) has well-developed flatwater and lentic zone with 57 families, 164 species, and 25 subspecies of plants. In particular, there are 20 families and 37 taxon of aquatic plants (Table 1) in or nearby the study area, and the representative species are Salix koreensis Andersson, Salix gracilistyl, Miscanthus sacchariflorus Benth, and Phragmites japonica Steud, which are located in eastern and southern waterside of the study area. Dominant species are Salix koreensis Andersson, Miscanthus sacchariflorus Benth on the whole area, and Phragmites japonica Steud, Artermisia princeps Pampanini-Erigeron Canadensis L. and Humulus japonicus grow in low-lying areas of right bank.

Surveyed vegetation was classified by the Degree of Green Naturality (DGN) and Vegetation Conservation Classification (VCC). The DGN is an indicator of the ecological characteristics of the green space with the rates on a scale of zero to ten. The VCC is the grade for evaluating the conservative value of vegetation, considering the location condition, vegetation succession, artificial disturbance and landscape of vegetation, and is used to effectively manage vegetative resources. Vegetation types in study area are shown in Table 2.

The study area has DGN 0 with free water surface, DGN 1 with bare ground, DGN 4 with short grassland vegetation, DGN 5 with long grassland vegetation, and DGN 7 with secondary forest, and there are no DGN 8 to 10 which are prohibited development. In the perspective of Vegetation Conservation Classification, the study area has normal conservation value (III) and high conservation value (V) grade. Specifically, Salix koreensis Andersson and Miscanthus sacchariflorus Benth inhabit the left bank of the study 
Table 1. Aquatic plants in Binae Wetland (M: Phanerophytes; N: Nanophanerophytes; H: Hemicryptophytes; HH: Hydrophytes; Th: Therophytes; G: Geophytes).

\begin{tabular}{|c|c|c|c|}
\hline Family & Scientific Name & Kind of plants & Life form \\
\hline Ceratophyllaceae & Ceratophyllum demersum L. & Submerged & $\mathrm{HH}$ \\
\hline \multirow{2}{*}{ Ranunculaceae } & Ranunculus japonicus & Emerged & $\mathrm{H}$ \\
\hline & Ranunculus sceleratus L. & Emerged & Th \\
\hline \multirow{2}{*}{ Polygonaceae } & Polygonum sagittatum L. & Emerged & Th \\
\hline & Persicaria thunbergii & Emerged & Th \\
\hline \multirow{5}{*}{ Salicaceae } & Salix glandulosa & Riparian & M \\
\hline & Salix gracilistyla & Riparian & $\mathrm{N}$ \\
\hline & Salix koreensis Andersson & Riparian & M \\
\hline & Salix koriyanagi Kimura & Riparian & $\mathrm{N}$ \\
\hline & Salix subfragilis Andersson & Riparian & M \\
\hline \multirow{2}{*}{ Brassicaceae } & Cardamine flexuosa With. & Emerged & Th \\
\hline & Cardamine leucantha & Emerged & $\mathrm{H}$ \\
\hline Crassulaceae & Penthorum chinense & Emerged & $\mathrm{HH}$ \\
\hline Trapaceae & Trapa japonica & Floating leaved & $\mathrm{HH}$ \\
\hline Onagraceae & Ludwigia epilobioides Maxim & Emerged & $\mathrm{H}$ \\
\hline Aceraceae & Acer ginnala & Riparian & M \\
\hline Balsaminaceae & Impatiens textori & Emerged & $\mathrm{H}$ \\
\hline Apiaceae & Oenanthe javanica & Emerged & $\mathrm{H}$ \\
\hline Labiatae & Stachys japonica Miq. & Emerged & $\mathrm{H}$ \\
\hline Scrophulariaceae & Veronica undulata Wall. & Emerged & $\mathrm{H}$ \\
\hline Compositae & Artemisia selengensis TURCZ. & Emerged & $\mathrm{H}$ \\
\hline \multirow{2}{*}{ Hydrocharitaceae } & Hydrilla verticillata & Submerged & $\mathrm{HH}$ \\
\hline & Vallisneria natans & Submerged & $\mathrm{HH}$ \\
\hline \multirow{2}{*}{ Potamogetonaceae } & Potamogeton crispus L. & Submerged & $\mathrm{HH}$ \\
\hline & Potamogeton malaianus Miq. & Submerged & $\mathrm{HH}$ \\
\hline Juncaceae & Juncus effusus var. decipiens & Emerged & $\mathrm{H}$ \\
\hline \multirow{3}{*}{ Cyperaceae } & Bolboschoenus yagara & Emerged & $\mathrm{H}$ \\
\hline & Scirpus tabernaemontani Gmel. & Emerged & $\mathrm{HH}$ \\
\hline & Scirpus triangulatus Roxb. & Emerged & $\mathrm{HH}$ \\
\hline \multirow{7}{*}{ Gramineae } & Echinochloa crusgalli var. & Emerged & Th \\
\hline & Leersia japonica & Emerged & $\mathrm{H}$ \\
\hline & Miscanthus sacchariflorus Benth. & Emerged & $\mathrm{H}$ \\
\hline & Phalaris arundinacea $\mathrm{L}$. & Emerged & $\mathrm{H}$ \\
\hline & Phragmites communis Trin. & Emerged & G \\
\hline & Phragmites japonica Steud. & Emerged & G \\
\hline & Zizania latifolia & Emerged & $\mathrm{HH}$ \\
\hline Typhaceae & Typha angustifolia L. & Emerged & $\mathrm{HH}$ \\
\hline
\end{tabular}

Table 2. Vegetation types in the study area with DGN and VCC.

\begin{tabular}{ccc}
\hline DGN & Vegetation Conservation Classification & Vegetation community (2012 - 2015 year) \\
\hline 0 & - & Water \\
\hline 1 & - & Bare Ground \\
\hline 4 & $\mathrm{~V}$ & Artermisia princeps Pampanini-Erigeron Canadensis L. \\
& & Humulus japonicus \\
\hline & $\mathrm{V}$ & Miscanthus sacchariflorus Benth. \\
& & Phragmites japonica Steud. \\
\hline 7 & III & Phragmites japonica Steud.-Salix koreensis Andersson \\
\hline
\end{tabular}


area as dominant species. Plants that appeared in the early succession habitat, such as Artermisia princeps Pampanini and Erigeron Canadensis L., were identified in the central area. Also, Humulus japonicus inhabit the forest and forest edge of Salix koreensis Andersson and short grassland vegetation. The spatial distribution of vegetation seems to remain the current type, until the disturbance occurs. The vegetation map of the study area from Fall 2012 to Summer 2015 is shown in Fig. 3.

Field surveys show that most of the communities change is in the upstream part of the study area. In 2013 to 2014, Humulus japonicus appeared in the front and left of the front area of the study area, and Erigeron Canadensis L. appeared in the left edge area. In 2014 to 2015, there were more changes than before, Humulus japonicus also have appeared in the central area that seems stabilized and in the middle of the right side. Miscanthus sacchariflorus Benth and Salix koreensis Andersson appeared in the rearend side of the study area in 2014 to 2015. Also, Carex dispalata Boott inhabitated the upstream area in 2012, but it was replaced by Humulus japonicas. One of the interesting observations is that the right front area has vigorous community changes during 4 years, and another one is that the central area shows less or no change. However, it is unclear why these areas show vigorous or less change.

\subsection{IEPs District Using Inundation Analysis}

To estimate the IEP of the study area, the flow duration curve that takes account of the changed runoff characteristic was estimated. The last 5 years of historical data record of water level on the Mokgye station, which is located 6.9 $\mathrm{km}$ above the mainstream from the study area on the Han River, was obtained from the Water Resources Management Information System (http://www.wamis.go.kr). These data were converted to runoff amount using a rating curve, which is a graph of discharge versus stage for a given point on a stream. The historical daily runoff data was found to have a generalized extreme value (GEV) distribution at 5\% level of significance by the Kolmogorov-Smirnov (stat $=0.032, \mathrm{p}=$ 0.0164) (Marsaglia et al. 2003) and Cramér-von Mises (stat $=0.042)$ (Stephens 2005) goodness of fit tests. The empirical and theoretical cumulative distribution functions of historical runoff were derived (Fig. 4). As shown in Fig. 4, each runoff amount that is in accordance with IEP was estimated, based on annual daily exceedance probability $(\mathrm{P}=0.01,0.03,0.05$, $0.08,0.25,0.50,0.75,0.97)$, as shown in Table 3 .

The topographic data of the study area were constructed, based on the cross-section data in the river channel from the Han River master plan (Ministry of Land, Transport and Maritime Affairs 2011) and digital elevation map with 1:5000 scale from National Spatial Information Clearinghouse (http://www.nsic.go.kr/ndsi/mapmainservice.do?menuId=MN0201). Missing or insufficient part of the topographic data were measured with Trimble R4 RTK GPS $( \pm 2 \mathrm{~cm})$ during field surveys, and the cross-sectional data were also measured with boat type Sontek ADP ${ }^{\circledR}$ (ADCP $\pm 0.5 \mathrm{~cm}$ ). Results show that the right bank has lowlying areas, and high elevation areas are concentrated on the left bank and central part of the study area. The constructed triangulated irregular network (TIN) is shown in Fig. 2.

To calibrate the inundation model based on section 2.2, two runoff events that occurred on 7 October 2012 and 10 October 2014 were simulated compared with ADCP observed results. The average root mean squared error (RMSE) (Hyndman and Khandakar 2007) between the inundation model simulation result and ADCP observation result was 0.645 and Pearson's correlation coefficient was 0.997. Therefore, it can be concluded that inundation model result does have explanatory power for actual observation data. Simulation results with each IEP are shown in Fig. 5.

As shown in Fig. 5, the upstream areas of the right bank are inundated from low IEPs $(\mathrm{P}=0.97)$, and downstream area of the right bank was starting to drown at the $\mathrm{P}$ $=0.50 \mathrm{IEP}$. The study area shows that inundation tends to concentrate on the right bank side, but left bank and central areas are not much inundated. For instance, in the $\mathrm{P}=0.25$ IEP, the upstream area of the right bank shows a $0.6-1.2 \mathrm{~m}$ inundation depth, and the downstream of the right bank and left bank shows $0.2-0.4 \mathrm{~m}$ inundation depth. The maximum inundation depth is $3.1 \mathrm{~m}$ on the right bank at $\mathrm{P}=0.01 \mathrm{IEP}$.

\subsection{Results and Discussion: Hydrological Regime Using IEPs and Vegetation}

Using inundation analysis, the study area can be divided into several IEP district areas, which are in accordance with the inundation frequency and water depth. It can be combined with vegetation map, because the vegetation species are affected by the inundation frequency and depth (Shafroth et al. 1998; Wassen et al. 2003; Ward et al. 2013; Howell and Benson 2000), and its results are shown in Fig. 6.

The IEP district, which is combined with vegetation communities change, in Fig. 6 shows the clue why the vegetation has actually changed. All areas that have vegetation changed belong to the IEP district, except Humulus japonicas community in the central area. Considering the IEP district, for a particular area that has annual submerged duration and depth, the submersion characteristics can be the reason that cause the disturbance of vegetation communities. For instance, the low-lying areas in the upstream part of the study area are the most vigorously changed areas, and they also belong to high submersion depth from $\mathrm{P}=0.25$ IEP. Moreover, the vegetation species that flowed into these areas (Humulus japonicas, Erigeron Canadensis L., Phragmites japonica Steud, Artermisia princeps Pampanini, Miscanthus sacchariflorus Benth) also have flooding tolerance (The Ministry of Environment 2007; Byun et al. 2008; Kim 


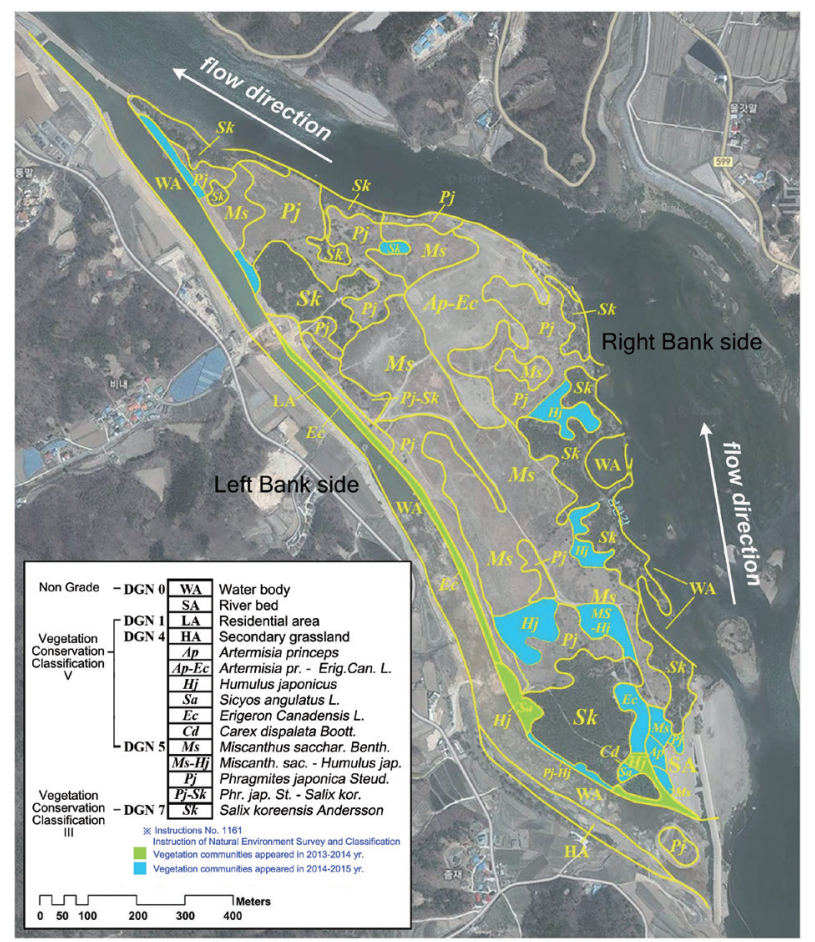

Fig. 3. Vegetation map of the study area (Binae Wetland); green area indicated that the communities appeared in 2013 - 2014, blue area indicated that the communities appeared in 2014 - 2015. (Color online only)

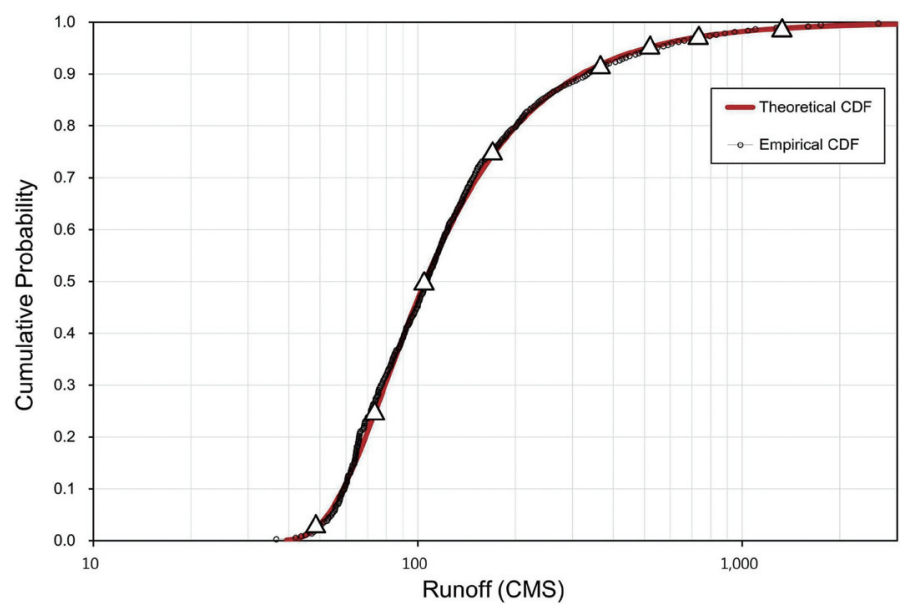

Fig. 4. Theoretical and empirical distributions function of runoff on the study area. (Color online only)

Table 3. Runoff amount for each IEP.

\begin{tabular}{c|ccc}
\hline Station & IEP $[\boldsymbol{P}(\boldsymbol{E})]$ & Runoff $\left(\mathbf{m}^{3} \mathbf{s}^{-1}\right)$ & Total duration of inundation per year (day) \\
\hline \multirow{5}{*}{ Mokgye } & 0.01 & 1,478 & 4 \\
& 0.03 & 710.5 & 10 \\
& 0.05 & 506.2 & 20 \\
& 0.08 & 370.7 & 30 \\
& 0.25 & 172.9 & 95 \\
& 0.50 & 105.2 & 185 \\
& 0.75 & 74.0 & 275 \\
& 0.97 & 49.6 & 355 \\
\hline
\end{tabular}




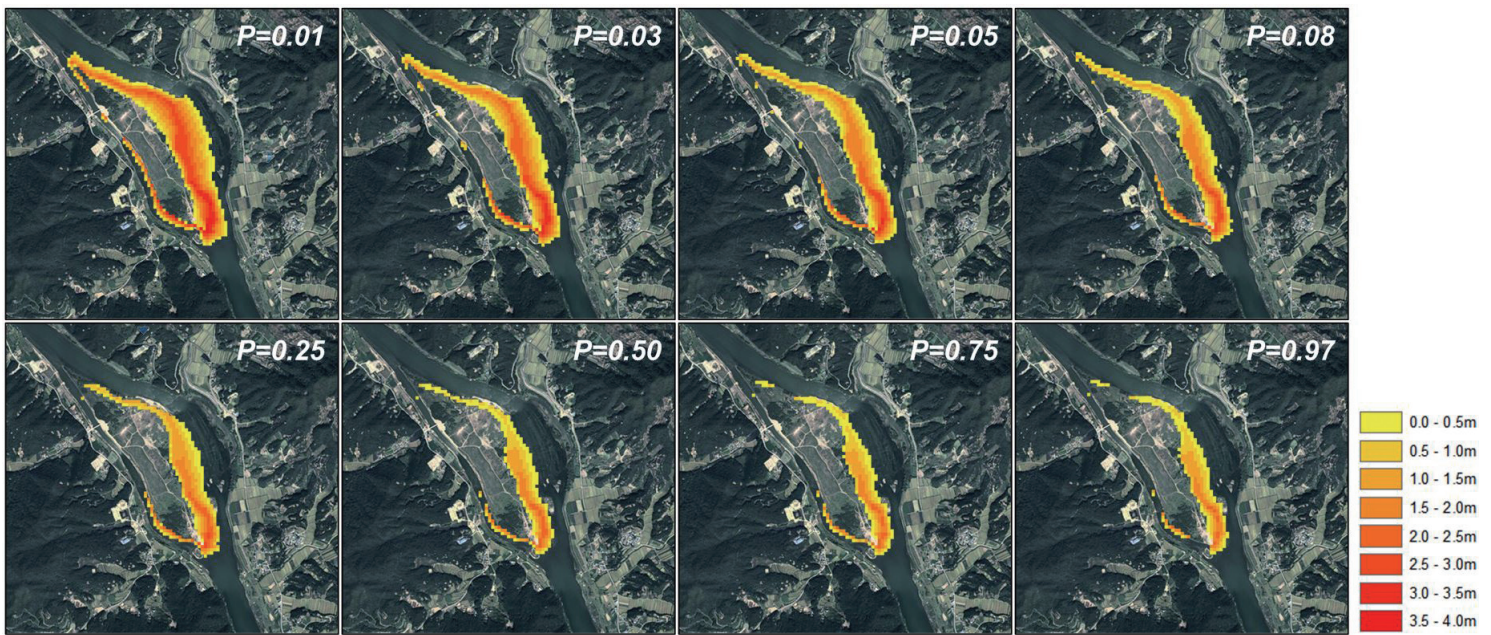

Fig. 5. Simulated inundation area and depth with each IEP (IEPs district map). (Color online only)

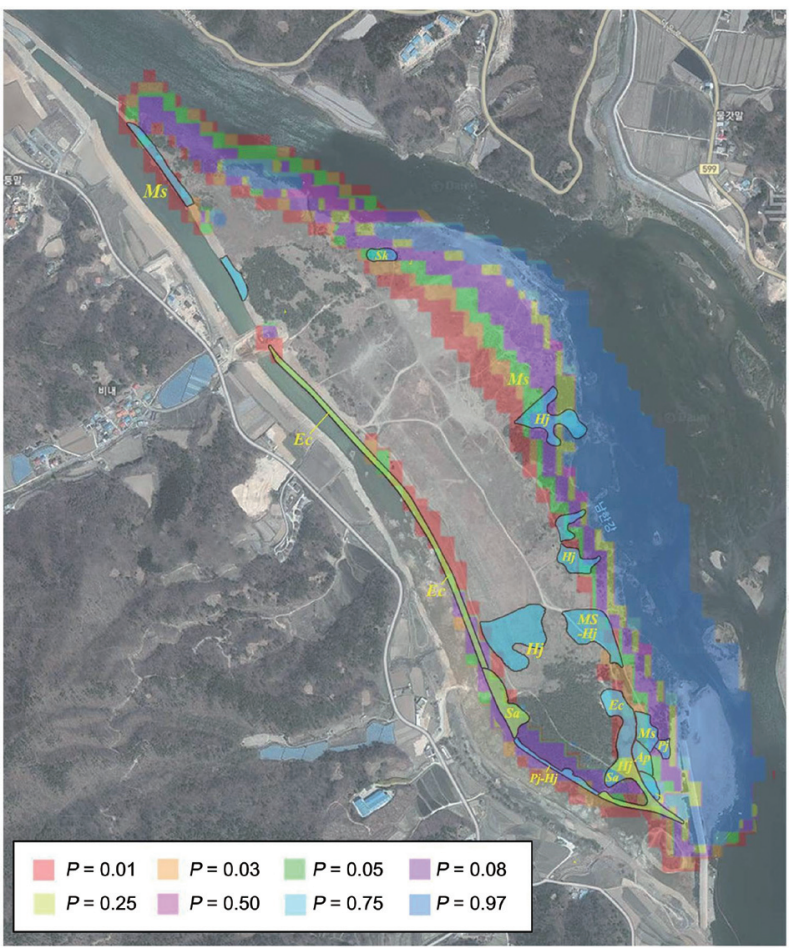

Fig. 6. IEP district map and vegetation change in the study area; high IEPs $(P=0.01,0.03, \ldots)$ include lower rank district. (Color online only)

et al. 2013; Oh 2015) or belong to the macrophyte plant. Of course, it could not be the only reason for vegetation change. However, there is no doubt that the hydrological regime with IEPs, including flood duration, frequency, and depth, could be the significant factor for vegetation change or succession, considering that most area of vegetation change are correlated with flood characteristics (IEPs) and numerous studies also support this observation (HowardWilliams 1975; Hughes 1990; Jean and Bouchard 1993; Gunderson 1994; Rea and Ganf 1994; Keddy 2000; Envi- ronment Canada 2002; Riis and Hawes 2002; Miller and Zedler 2003; Agostinho et al. 2004; Van Der Valk 2005; Frieswyk and Zedler 2007; Maltchik et al. 2007; Aroviita and Hämäläinen 2008; Wilcox and Nichols 2008; Todd et al. 2010; Nam et al. 2015).

The IEP district map also shows more detailed data for vegetation communities. It could be the elementary data to evaluate the vulnerability and prediction of vegetation distribution and succession. Specifically, from the perspective of the study area, Salix koreensis Andersson have inhabited 
both sides of the upstream area. The left bank group does not have any IEP district, but the right bank group shows that vegetation communities were fully inundated with the $\mathrm{P}=0.25$ IEP district. Also, vigorously changed areas are belonging to the $\mathrm{P}=0.25$ or lower IEPs district area and it is equivalent to totally 95 inundation period per year. As per Kim et al. (2013), they stopped growing in submersion, and the number of leaves became only $19.4 \%$ in 20 days of submersion with turbidity in the flood season. Therefore, Salix koreensis Andersson in the right bank area was more vulnerable than in the left bank group. Also, Humulus japonicas inhabit in the Salix koreensis Andersson communities on the right bank in summer season. It also seems to be caused by submersion, which can be described with IEPs, because Humulus japonicas has a tendency that it has a rapid growth rate (approximately $800 \mathrm{~g} \mathrm{~m}^{-2}$ ) and is limiting other vegetation productivity during its growth period. Especially, the growth rate of Humulus japonicas is not influenced unless fully submersed, and it rapidly increases after submersion (The Ministry of Environment 2007). Therefore, it does not influence submersion problem when Salix koreensis Andersson is having it. That is the reason it seems that it rapidly grows in Salix koreensis Andersson communities after the submersion period. Also, Artermisia princeps Pampanini and Miscanthus sacchariflorus Benth show similar flooding tolerance with Salix koreensis Andersson and growth rates are depressed when the submersion period becomes longer than 10 days (Oh 2015). Phragmites japonica Steud inhabits the areas that have $0-0.3 \mathrm{~m}$ water depth. So, it is not much influenced by submersion or flooding. It also gives the clue why Humulus japonicas appeared in central area. Changed communities in central area were covered by Phragmites japonica Steud and Erigeron Canadensis L. in 2012 (newly reconstructed), but Humulus japonicas appeared in 2014. It seems to be the part of natural succession, considering its rapid growth rate and limiting other vegetation productivities. Otherwise, Erigeron Canadensis L. is common in grasslands and in most disturbed sites, including riparian and wetland areas, but it does not belong to macrophytes species and is vulnerable to submersion. Therefore, all of them except hydrophilic vegetation are highly dependent on the frequency, depth and duration of inundation (Asaeda and Rajapakse 2008), and plant communities are also vulnerable when the IEP goes under the $\mathrm{P}=0.08$ IEP district, or seems to be transit to hydrophilic vegetation, such as Phragmites japonica Steud. Since the right bank of the study area has the probability that can be disrupted by flooding and submersion (Dauer et al. 2007), the area needs further monitoring and investigation in order to understand continuous plant succession. Also, some plant communities on the right bank, including Salix koreensis Andersson, Erigeron Canadensis L., etc., need concentrated effort for their succession. Consequently, the areas with $\mathrm{P}=0.08$ or lower IEPs should have the disturbance for vegetation communi- ties, or could be changed to a hydrophilic vegetation, and it should be considered in the restoration and rehabilitation project in the study area. Also, given the IEP results, flow regulation standard may have to be changed to conserve legally protected or endangered vegetation.

One of the limitations of this study is the shortage of survey. There are eight field surveys after 4 years from the end of construction. Longer monitoring is needed to clarify vegetation succession (US Fish and Wildlife Service 1999). Hydrological characteristics could not be the only reason of succession, but it also has the meaning that it shows an overall trend of succession in the riparian wetlands. Another limitation is the concept of IEP that does not take into account time series characteristics. For instance, $\mathrm{P}=0.08$ IEP means the total period (30 days) of submersion, so it does not guarantee 30 days of continuous submersion period. However, there is no doubt that the total submersion period will have an influence on the riparian zone and wetland plant species. Therefore, the next step of this study is to conduct time series analysis for submersion, based on the IEP concept, but it needs longer period survey and data collection. Also, results of this study suggest a way to connect hydrological characteristics and vegetation communities base on the IEPs district map (Fig. 7), and provide a methodology for the evaluation and prediction that are essential to have the ecological assessment for wetland restoration, hydrological engineering project and climate change. It could be used to find a proper plant species for the constructed wetland, river bank, ecological area, and waterfront spaces.

\section{CONCLUSION}

The spatial and temporal succession of vegetation has been recognized as one of the important factors to understand riparian ecosystems during the last decades (Zhang et al. 2012). This study aims at connecting hydrological characteristics and vegetation, and suggests a methodology to approach this connection. The Biane wetland, which is a highly dynamic and diverse area and located in the mainstream of Han River that has been influenced by the Four Major River Restoration Project, was selected as the study area and has been surveyed from the end of the project. Using field survey data for vegetation and hydrological characteristics during 2012 to 2015, vegetation and DEM are estimated. Also, the IEP and its district concept are proposed to gain insights into hydrological characteristics, including inundation frequency, duration and depth, in relation to vegetation distribution. Based on daily annual inundated exceedance frequency and its runoff amount $(\mathrm{P}=0.01$, $0.03,0.05,0.08,0.25,0.50,0.75,0.97)$, IEPs and their district that are described by the inundation duration and depth are estimated using two dimensional inundation analysis. This paper shows that the hydrological regime is the driving factor for vegetation change in the riparian wetland. By 


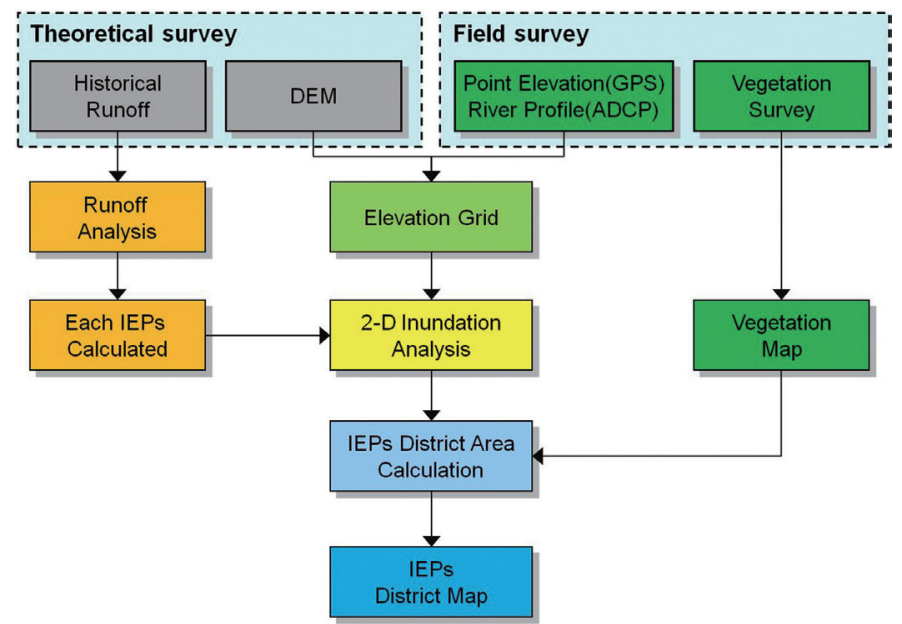

Fig. 7. Diagram to estimate the IEP district map. (Color online only)

plotting the IEP district and combining its result with vegetation map, this study illustrates that the spatial distribution and change of plant communities are in close association with hydrological characteristics and describe the vulnerability for each IEPs. Specifically, some plant communities, such as Salix koreensis Andersson, Erigeron Canadensis L. on the right bank are determined to be more vulnerable than other areas. Consequently, the areas with $\mathrm{P}=0.08$ or lower IEPs should have the disturbance for vegetation communities, or could be changed to a hydrophilic vegetation in the study area. Also, given the IEP results, flow regulation standard may have to be changed to conserve legally protected or endangered vegetation. Results from this study suggest a way to connect hydrological characteristics and vegetation communities, and this connection should be considered in the restoration and rehabilitation project.

Acknowledgements This research was supported by a grant (MOIS-DP-2015-05) through the Disaster and Safety Management Institute funded by Ministry of the Interior and Safety of Korean government.

\section{REFERENCES}

Acreman, M. C., J. R. Blake, D. J. Booker, R. J. Harding, N. Reynard, J. O. Mountford, and C. J. Stratford, 2009: A simple framework for evaluating regional wetland ecohydrological response to climate change with case studies from Great Britain. Ecohydrology, 2, 1-17, doi: 10.1002/eco.37. [Link]

Agostinho, A. A., S. M. Thomaz, and L. C. Gomes, 2004: Threats for biodiversity in the floodplain of the Upper Paraná River: Effects of hydrological regulation by dams. Int. J. Ecohydrology \& Hydrobiology, 4, 255-268.

Aroviita, J. and H. Hämäläinen, 2008: The impact of water- level regulation on littoral macroinvertebrate assemblages in boreal lakes. Hydrobiologia, 613, 45-56, doi: 10.1007/s10750-008-9471-4. [Link]

Asaeda, T. and L. Rajapakse, 2008: Effects of spates of different magnitudes on a Phragmites japonica population on a sandbar of a frequently disturbed river. River Res. Appl., 24, 1310-1324, doi: 10.1002/rra.1128. [Link]

Boar, R. R., 2006: Responses of a fringing Cyperus papyrus L. swamp to changes in water level. Aquat. Bot., 84, 85-92, doi: 10.1016/j.aquabot.2005.07.008. [Link]

Braun-Blanquet, J., 1964: Pflanzensoziologie: Grundzüge der Vegetationskunde, Springer Vienna, Wien, New York, doi: 10.1007/978-3-7091-8110-2. [Link]

Bridgham, S. D., K. Updegraff, and J. Pastor, 1998: Carbon, nitrogen, and phosphorus mineralization in northern wetlands. Ecology, 79, 1545-1561, doi: 10.1890/00129658(1998)079[1545:cnapmi]2.0.co;2. [Link]

Busch, D. E., W. F. Loftus, and O. L. Bass, 1998: Long-term hydrologic effects on marsh plant community structure in the southern Everglades. Wetlands, 18, 230-241, doi: 10.1007/bf03161658. [Link]

Byun, C. H., G. J. Kwon, D. W. Lee, J. M. Wojdak, and J. G. Kim, 2008: Ecological assessment of plant succession and water quality in abandoned rice fields. J. Ecol. Environ., 31, 213-223, doi: 10.5141/jefb.2008.31.3.213. [Link]

Capon, S. J., 2005: Flood variability and spatial variation in plant community composition and structure on a large arid floodplain. J. Arid Environ., 60, 283-302, doi: 10.1016/j.jaridenv.2004.04.004. [Link]

Catford, J. A., B. J. Downes, C. J. Gippel, and P. A. Vesk, 2011: Flow regulation reduces native plant cover and facilitates exotic invasion in riparian wetlands. J. Appl. Ecol., 48, 432-442, doi: 10.1111/j.13652664.2010.01945.x. [Link]

Cellot, B., M. J. Dole-Olivier, G. Bornette, and G. Pautou, 
1994: Temporal and spatial environmental variability in the Upper Rhône River and its floodplain. Freshwat. Biol., 31, 311-325, doi: 10.1111/j.1365-2427.1994. tb01743.x. [Link]

Cha, Y. J., M. P. Shim, and S. K. Kim, 2011: The Four Major Rivers Restoration Project. Proceedings of the UNWater International Conference, Zaragoza, Spain, 3-5 October 2011, UN-Water.

Dauer, J. T., D. A. Mortensen, and M. J. Vangessel, 2007: Temporal and spatial dynamics of long-distance Conyza canadensis seed dispersal. J. Appl.Ecol., 44, 105114, doi: 10.1111/j.1365-2664.2006.01256.x. [Link]

David, P. G., 1996: Changes in plant communities relative to hydrologic conditions in the Florida Everglades. Wetlands, 16, 15-23, doi: 10.1007/bf03160642. [Link]

Dawson, T. P., P. M. Berry, and E. Kampa, 2003: Climate change impacts on freshwater wetland habitats. J. Nat. Conservat., 11, 25-30, doi: 10.1078/1617-1381-00031. [Link]

Eliot, I., C. M. Finlayson, and P. Waterman, 1999: Predicted climate change, sea-level rise and wetland management in the Australian wet-dry tropics. Wetlands Ecology and Management, 7, 63-81, doi: 10.1023/ a:1008477110382. [Link]

Environment Canada, 2002: Where Land Meets Water: Understanding Wetlands of the Great Lakes, Canadian Wildlife Service, Downsview, ON, Canada.

Frieswyk, C. B. and J. B. Zedler, 2007: Vegetation change in Great Lakes coastal wetlands: Deviation from the historical cycle. J. Great Lakes Res., 33, 366-380, doi: 10.3394/0380-1330(2007)33[366:vciglc]2.0.co;2. [Link]

Girel, J., 1994: Old distribution procedure of both water and matter fluxes in floodplains of western Europe: impact on present vegetation. Environ. Manage., 18, 203-221, doi: 10.1007/bf02393762. [Link]

Gunderson, L. H., 1994: Vegetation of the Everglades: Determinants of community composition. In: Davis, S. and J. C. Ogden (Eds.), Everglades: The Ecosystem and Its Restoration, St. Lucie Press, Delray Beach, FL, 323-340.

Hill, D., M. Fasham, G. Tucker, M. Shewry, and P. Shaw, 2005: Handbook of Biodiversity Methods: Survey, Evaluation and Monitoring, Cambridge University Press, Cambridge, UK, 219-222, doi: 10.1017/ CBO9780511542084. [Link]

Howard-Williams, C., 1975: Vegetation changes in a shallow African lake: Response of the vegetation to a recent dry period. Hydrobiologia , 47, 381-398, doi: 10.1007/ bf00039584. [Link]

Howell, J. and D. Benson, 2000: Predicting potential impacts of environmental flows on weedy riparian vegetation of the Hawkesbury-Nepean River, south-eastern Australia. Austral Ecology, 25, 463-475, doi: 10.1046/ j.1442-9993.2000.01084.x. [Link]

Hughes, F. M. R., 1990: The influence of flooding regimes on forest distribution and composition in the Tana River floodplain, Kenya. J. Appl. Ecol., 27, 475-491, doi: 10.2307/2404295. [Link]

Hughes, F. M. R., 1997: Floodplain biogeomorphology. Prog. Phys. Geogr., 21, 501-529, doi: 10.1177/030913339702100402. [Link]

Hyndman, R. J. and Y. Khandakar, 2007: Automatic time series for forecasting: The forecast package for R (No. 6/07). Monash University, Department of Econometrics and Business Statistics.

Iwasa, Y., K. Inoue, and M. Mizutori, 1980: Hydraulic analysis of overland flood flows by means of numerical method. Disaster Prevention Research Institute Annuals, 23, 305-317. (in Japanese)

Jean, M. and A. Bouchard, 1993: Riverine wetland vegetation: importance of small-scale and large-scale environmental variation. J. Veg. Sci., 4, 609-620, doi: 10.2307/3236126. [Link]

Johnson, W. C., B. V. Millett, T. Gilmanov, R. A. Voldseth, G. R. Guntenspergen, and D. E. Naugle, 2005: Vulnerability of northern prairie wetlands to climate change. BioScience, 55, 863-872, doi: 10.1641/00063568(2005)055[0863:vonpwt]2.0.co;2. [Link]

Keddy, P. and L. H. Fraser, 2000: Four general principles for the management and conservation of wetlands in large lakes: The role of water levels, nutrients, competitive hierarchies and centrifugal organization. Lakes \& Reservoirs: Research \& Management, 5, 177-185, doi: 10.1046/j.1440-1770.2000.00111.x. [Link]

Keddy, P. A, 2000: Wetland Ecology: Principles and Conservation, Cambridge University Press, Cambridge, UK.

Kennedy, M. P., J. M. Milne, and K. J. Murphy, 2003: Experimental growth responses to groundwater level variation and competition in five British wetland plant species. Wetlands Ecology and Management, 11, 383-396, doi: 10.1023/b:wetl.0000007194.01073.6b. [Link]

Kim, J. T., E. J. Kim, J. G. Kang, and H. K. Yeo, 2013: Variation on the growth rate of plants by submersion of high turbidity -A case study on Salix species-. $J$. Kor. Water Resour. Assoc., 46, 957-967, doi: 10.3741/ jkwra.2013.46.9.957. (In Korean) [Link]

Kim, K. G., H. Lee, and D. H. Lee, 2011: Wetland restoration to enhance biodiversity in urban areas: A comparative analysis. Landsc. Ecol. Eng., 7, 27-32, doi: 10.1007/s11355-010-0144-x. [Link]

Large, A. R. G., 1997: Linking floodplain hydrology and ecology - the scientific basis for management. BHS Occasional Paper No. 8, Floodplain Rivers: Hydrological Processes and Ecological Significance, British Hydrological Society, 1-5.

Large, A. R. G., K. Prach, M. A. Bickerton, and P. M. Wade, 1994: Alteration of patch boundaries on the floodplain 
of the regulated River Trent, UK. Regulated Rivers: Research \& Management, 9, 71-78, doi: 10.1002/ rrr.3450090108. [Link]

Lenders, H. J. R., B. G. W. Aarts, H. Strijbosch, G. Van der Velde, P. H. Nienhuis, R. S. E. Leuven, and A. M. J. Ragas, 1999: The role of reference and target images in ecological recovery of river systems: Lines of thought in the Netherlands. In: Nienhuis, P. H., R. S.E. Leuven, and A. M. J. Ragas (Eds.), New Concepts for Substainable Management of River Basins, Backhuys, Netherlands, 35-52.

Maltchik, L., A. S. Rolon, and P. Schott, 2007: Effects of hydrological variation on the aquatic plant community in a floodplain palustrine wetland of southern Brazil. Limnology, 8, 23-28, doi: 10.1007/s10201-006-0192-y. [Link]

Marsaglia, G., W. W. Tsang, and J. Wang, 2003: Evaluating Kolmogorov's Distribution. J. Stat. Software, 8, 1-4, doi: 10.18637/jss.v008.i18. [Link]

McCollin, D., L. Moore, and T. Sparks, 2000: The flora of a cultural landscape: Environmental determinants of change revealed using archival sources. Biol. Conservat., 92, 249-263, doi: 10.1016/s0006-3207(99)00070-1. [Link]

Miller, R. C. and J. B. Zedler, 2003: Responses of native and invasive wetland plants to hydroperiod and water depth. Plant Ecol., 167, 57-69, doi: 10.1023/ a:1023918619073. [Link]

Ministry of Land, Transport and Maritime Affairs, 2011: Han River MasterPlan (Supplement) (Paldangdam Chungjudam) Report. (in Korean)

Mitsch, W. J. and J. G. Gosselink, 2007: Wetlands, WILEY, Hoboken, NJ, US.

Nam, J. M., H. S. Cho, and J. G. Kim, 2015: Effect of Plant Life Cycle on Plant Settlement in Diverse Water Level. J. Wetlands Res., 17, 19-25, doi: 10.17663/ jwr.2015.17.1.019. (in Korean) [Link]

Oh, S. H., 2015: Analysis of ecological niche of dominant plants in riverine ecosystem. Master Thesis, Gangneung-Wonju National University. (in Korean)

Olmsted, I. C. and T. V. Armentano, 1997: Vegetation of Shark Slough, Everglades National Park. Homestead, FL: South Florida Natural Resources Center, Everglades National Park.

Rea, N. and G. G. Ganf, 1994: How emergent plants experience water regime in a Mediterranean-type wetland. Aquat. Bot., 49, 117-136, doi: 10.1016/0304-3770(94)90033-7. [Link]

Rho, P. H., 2007: Spatio-Temporal Dynamics of Estuarine Wetlands Related to Watershed Characteristics in the Han River Estuary. J. Kor. Geogr. Soc., 42, 344-354. (in Korean)

Rich, T. C. G. and E. R. Woodruff, 1996: Changes in the vascular plant floras of England and Scotland be- tween 1930-1960 and 1987-1988: The BSBI monitoring scheme. Biol. Conservat., 75, 217-229, doi: 10.1016/0006-3207(95)00077-1. [Link]

Riis, T. and I. Hawes, 2002: Relationships between water level fluctuations and vegetation diversity in shallow water of New Zealand lakes. Aquat. Bot., 74, 133-148, doi: 10.1016/s0304-3770(02)00074-8. [Link]

Ross, M. S., D. L. Reed, J. P. Sah, P. L. Ruiz, and M. T. Lewin, 2003: Vegetation: Environment relationships and water management in Shark Slough, Everglades National Park. Wetlands Ecology and Management, 11, 291-303, doi: 10.1023/b:wetl.0000005541.30283. 11. [Link]

Scholz, M. and B. H. Lee, 2005: Constructed wetlands: a review. Int. J. Environ. Stud., 62, 421-447, doi: 10.1080/00207230500119783. [Link]

Seo, Y. J., D. C. Seo, I. W. Choi, B. J. Lim, J. H. Park, K. S. Kim, and J. S. Cho, 2011: Growth characteristics and nutrient loads of submerged plants in flood control reservoir around Juam lake. Korean J. Soil Sci. Fertilizer, 44, 922-928, doi: 10.7745/kjssf.2011.44.5.922. [Link]

Shafroth, P. B., G. T. Auble, J. C. Stromberg, and D. T. Patten, 1998: Establishment of woody riparian vegetation in relation to annual patterns of streamflow, Bill Williams River, Arizona. Wetlands, 18, 577-590, doi: 10.1007/bf03161674. [Link]

Stephens, M. A., 2005: Tests Based on EDF Statistics. In: D'Agostino, R. B. and M. A. Stephens (Eds.), Goodness-of-Fit Techniques, New York: Marcel Dekker, ISBN 0-8247-7487-6.

Suzuki, T., H. Shibaki, and K. Suzuyama, 2014: The numerical analysis of wave overtopping and water overflow over the coastal levee in the storm condition. Coast. Eng. Proc., 1, doi: 10.9753/icce.v34.waves.9. [Link]

Swanson, F. J., S. V. Gregory, J. R. Sedell, and A. G. Campbell, 1982: Chapter 9 - Land-water interactions: The riparian zone. In: Edmonds, R. L. (Ed.), Analysis of Coniferous Forest Ecosystems in the Western United States, Hutchinson Ross Pub. Co., Stroudsburg, Pa., 267-291.

The Ministry of Environment, 2007: Ecological Risk Assessment and Management of Invasive Vines for Biodiversity and Ecological Functions in Riverine Wetland, Korea. (in Korean)

Todd, M. J., R. Muneepeerakul, D. Pumo, S. Azaele, F. Miralles-Wilhelm, A. Rinaldo, and I. Rodriguez-Iturbe, 2010: Hydrological drivers of wetland vegetation community distribution within Everglades National Park, Florida. Adv. Water Resour., 33, 1279-1289, doi: 10.1016/j.advwatres.2010.04.003. [Link]

Tremolieres, M., U. Roeck, J. P. Klein, and R. Carbiener, 1994: The exchange process between river and groundwater on the central Alsace floodplain (Eastern France): II. The case of a river with functional 
floodplain. Hydrobiologia, 273, 19-36, doi: 10.1007/ bf00126766. [Link]

US Fish and Wildlife Service, 1999: Hawai'ian Wetland Refuge Habitat Management Review. United States Fish and Wildlife Service Refuges and Wildlife Region I, Portland, Oregon.

Van Der Valk, A. G., 2005: Water-level fluctuations in North American prairie wetlands. Hydrobiologia, 539, 171-188, doi: 10.1007/s10750-004-4866-3. [Link]

Van Oorschot, M., E. Robbemont, M. Boerstal, I. Van Strien, and M. Van Kerkhoven-Schmitz, 1997: Effects of enhanced nutrient availability on plant and soil nutrient dynamics in two English riverine ecosystems. $J$. Ecol., 85, 167-179, doi: 10.2307/2960649. [Link]

Wall, G., 1998: Implications of global climate change for tourism and recreation in wetland areas. Clim. Change, 40, 371-389, doi: 10.1023/a:1005493625658. [Link]

Ward, D. P., S. K. Hamilton, T. D. Jardine, N. E. Pettit, E. K. Tews, J. M. Olley, and S. E. Bunn, 2013: Assessing the seasonal dynamics of inundation, turbidity, and aquatic vegetation in the Australian wet-dry tropics using optical remote sensing. Ecohydrology, 6, 312-323, doi: 10.1002/eco.1270. [Link]

Wassen, M. J., W. H. M. Peeters, and H. O. Venterink, 2003: Patterns in vegetation, hydrology, and nutrient availability in an undisturbed river floodplain in Poland. Plant Ecol., 165, 27-43, doi: 10.1023/ a:1021493327180. [Link]

Wilcox, D. A. and S. J. Nichols, 2008: The effects of waterlevel fluctuations on vegetation in a Lake Huron wetland. Wetlands, 28, 487-501, doi: 10.1672/07-129.1. [Link]

Yu, J. and P. Wang, 2012: Relationship between water and vegetation in the Ejina Delta. Bull. Chin. Acad. Sci., 26, 68-75.

Zhang, L., J. Yin, Y. Jiang, and H. Wang, 2012: Relationship between the hydrological conditions and the distribution of vegetation communities within the Poyang Lake National Nature Reserve, China. Ecol. Informat., 11, 65-75, doi: 10.1016/j.ecoinf.2012.05.006. [Link]

Zweig, C. L. and W. M. Kitchens, 2008: Effects of landscape gradients on wetland vegetation communities: Information for large-scale restoration. Wetlands, 28, 1086-1096, doi: 10.1672/08-96.1. [Link] 